\title{
Mads Lange til Bali gennem historiens nåleøje
}

af forskningbibliotekar, dr.phil. John T. Lauridsen

I maj 1856 døde en dansk købmand ved navn Mads Langei al ubemærkethed på øen Bali i Ostindien. Han blev 48 år. Nyheden nåede familien i Rudkøbing i august og kun en lille notits om hans død stod kort efter i aviserne, underskrevet af forældre og brødre. Derefter sænkede historiens mørke sig omkring ham, næsten da. Enkelte gange senere bragte aviser en spalte om hans liv. Det var det hele ${ }^{1}$.

I første del af 1920'erne var den unge rejsebogsforfatter Aage Krarup Nielsen på jagt efter stof til sin fjerde bog. En smuk samling billeder fra Bali inspirerede ham til at tage dertil, og fra en dansk ingeniør på stedet hørte han om en landsmand, Mads Lange, som for 100 år siden skulle have været en mægtig mand på stedet. Det satte Krarup Nielsen på sporet af Mads Langes historie, og i 1925 kom på forlaget H. Aschehoug \& Co bogen Mads Lange til Bali. En dansk Ostindienfarers liv og æeventyr. Bogen blev et nyt gennembrud for Krarup Nielsen og især for Mads Lange i forhold til den brede offentlighed.Krarup Nielsen havde brugt mere research på denne end sine tidligere bøger. Hans egne rejseind tryk fra Bali blev ført sammen med det sparsomme materiale, mundtligt som skriftligt, om Mads Lange, som var til rådighed. Krarup Nielsen havde sat sig i forbindelse med efterkommere af Mads Lange, fremskaffet breve af Lange eller afskrifter af samme og havde fået nogle hollandske kilder oversat ${ }^{2}$. Dog var det næppe alene det, deri den grad gjorde bogen til en succes. Nok handlede den om et usædvanligt liv, “... et af de eventyr, som livet har digtet mere vidunderligt, end vi mennesker formår" (Aage Krarup Nielsen i sine erindringer), men sund forretningssans havde for en sikkerheds skyld fået forlag og forfatter til at forsyne den med 


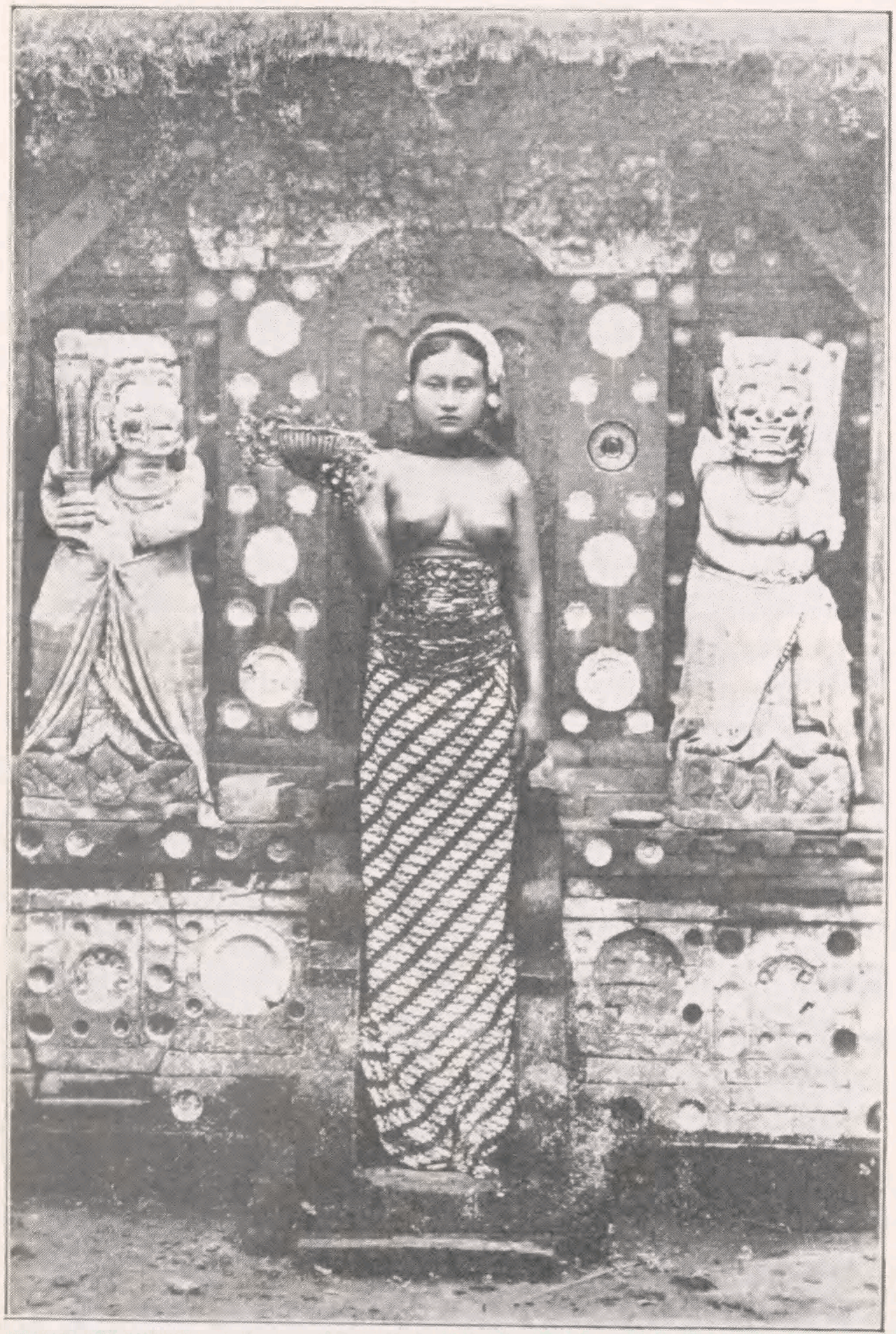

Gudernes gave. - Illustration fra Aage Krarup-Nielsens bog Mads Lange til Bali. 
en lang række aktuelle fotos fra det eksotiske Bali, hvor en del indfødte piger viste sig i deres maleriske dragter med blottet barm. Antallet af den slags fotos var uforholdsmæssigt i forhold til deres relevans, men bidrog ganske givet til salget i en tid, hvor sådanne fotos ellers enten blev solgt under kioskdisken eller hørte hjemme i kunsthistorien.

Krarup Nielsen ændrede i teksten efter udgivelsen af 1 . oplag, idet Mads Langes testamente kom til hans kendskab ${ }^{3}$, men dog kunne forlaget ikke beslutte sig til, om det herefter var en ny udgave eller et nyt oplag, så begge oplysninger optræder i de senere udgaver/oplag ${ }^{4}$. Bogen opnåede sit 5. og sidste oplag i 1949 og var dermed trykt i ialt 38.000 eksemplarer, (foruden en hollandsk udgave i 1928), men på det tidspunkt havde den forlængst sikret, at Mads Lange var trukket ud af det historiske mørke for bestandig.

Mads Lange var omkring 1900 ikke kendt og værdsat nok til, at C.F. Bricka som redaktør af Dansk Biografisk Leksikon tog ham med. Dansk Biografisk Leksikons anden udgave fremkom i 1930'erne derimod med en artikel om Lange, forfattet af Kay Larsen. Den fortalte i knap form, hvad Krarup Nielsen havde brugt næsten 150 sider på. Ud over handelsvirksomheden, som ikke i sig selv var bemærkelsesværdig, men nok omfattende, så havde Lange ind taget en nøgleposition i forholdet mellem de hollandske kolonisatorer og den balinesiske lokalbefolkning. Den post havde han håndteret med en sådan smidighed og diplomatisk snilde, at både lokalbefolkningen og hollænderne nærede stor respekt for ham. Takket være ham blev større blodsudgydelser undgået. Dette kunststykke gav ham et varigere navn både på Bali og hos hollandske koloniembedsmænd. Hvad embedsmændeneikke havde kunnet opnå med krig og besættelse, klarede Lange ad forhandlingens vej, tilmed så han ikkesolgtelokalbefolkningens interesserog selvstændighed. Det lyder som en ganske umulig og i hvert fald utrolig opgave. Det gav stof til eventyr og historier om ham.

Selv leverede Mads Lange også enkelte bidrag til historien. Med generøsitet forærede han bl.a. et par kostbare og smukke figurer og en balinesisk kalender til Nationalmuseet i 1850 ' erne $^{5}$. Af hans eget arkiv er så godt som alt forsvundet, med enkelte undtagelser. Foruden de ovenfor nævnte breve, indsamlet af Krarup Nielsen, drejer det sig om noglebalinesiske breve skrevet på palmeblade med tekst af eller til ham selv og andre. Defleste 


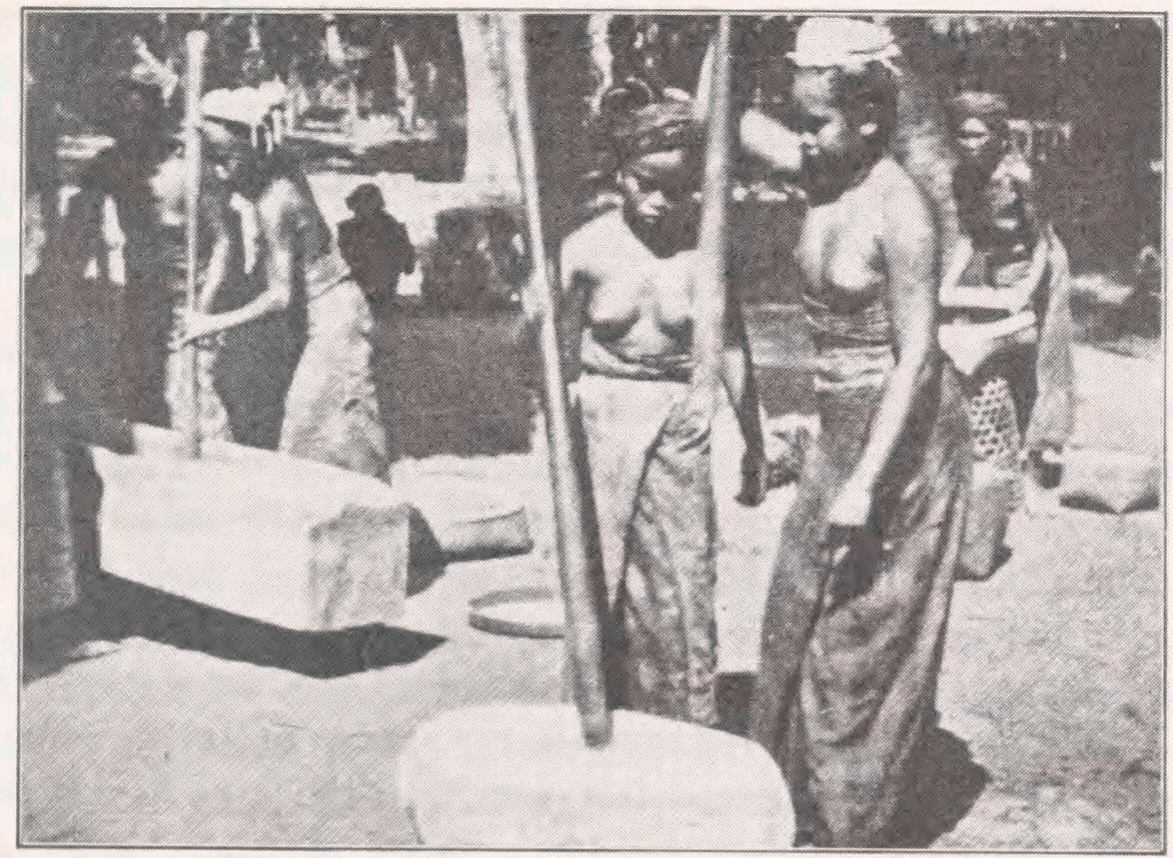

Medens Kvinderne grutter Ris,

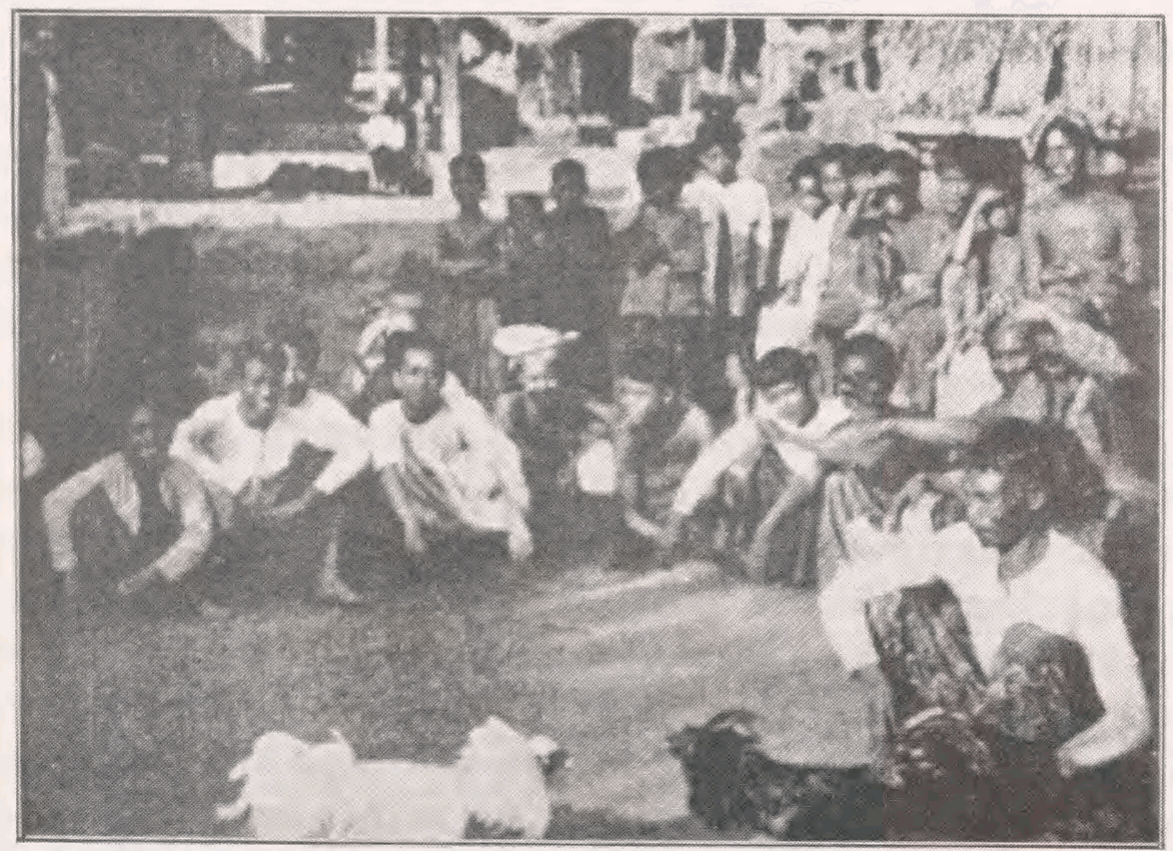

ser Mændene paa Hanekamp. 
(6 af 7) af disse er nu i Det kongelige Biblioteks besiddelse og blev publiceret i $1977^{6}$. Dem kendte Aage Krarup Nielsen desværre ikke, før han skrev sin bog, idet de først kom til biblioteket i 1936, men på et interessant punkt fortæller de mere om Langes privatliv. Han var ikke formelt gift, den uopnåelige kvinde, kusinen Ida Bay, sad ugift i Rudkøbing hele sit liv, men det var bl.a. breve fra eller vedrørende hans elskerinder på Bali, en kineser og en balineser, der fik lov til at overleve til eftertiden. De giver et enestående indblik i forholdet mellem købmanden fra Rudkøbing og de kvinder, der tjente som stedfortrædere for Ida Bay. Brevene efterlader mere et indtryk af en forretningsmæssig end en følelsesmæssig tilknytning. Et varigere resultat af disse forbindelser var, at Mads Lange fik efterkommere på Bali, som ved ægteskaber opnåede fyrstelig rang.

I de senere år har der været en stigende interesse for forskellige sider af Mads Langes virksomhed. Hollænderen, historikeren og Bali-specialisten HenkSchultze Nordholdt leveredei 1981 en meget sympatisk tegnet skildring af vilkårene for Langes virke, som både handelsmand og mægler mellem de lokale autoriteter og kolonimagten. Nordholdt trækker i beskedent omfang på et nyt kildemateriale og derudover redegør han for magtstrukturen på Bali og fremmedes muligheder for at opnå rettigheder, indflydelse og stillinger i forhold til magthaverne på øen ${ }^{7}$. Siden fulgte i 1990 Jørgen E. Møllers nye forsøg på at analysere Mads Langes handel fra Bali eller rettere mulighederne for den handel, men det er begrænset, hvor langt han har kunnet nå, også i forhold til Nordholdt, da fraværet af et handelsarkiv som kildemateriale til den slags undersøgelser er helt afgørende for resultatet. Derfor kommer konklusionen, at det var den rette mand på det rette sted til at stå noget uforpligtende ${ }^{8}$. For hvad ellers, fristes man til at spørge?

Til gengæld kan Møllers kritik af Nordholdt for ganske at underbetone den politiske Mads Lange have noget på sig. I Nordholdts portræt er Lange den politisk uinteresseredehandelsmand, som koncentrerer sig om handelen og kun lader sig indblande i politik, hvis det har betydning for handelen. Handel og politik var så nært forbundne på Bali i denne periode, at den fremmede var nødt til at have indgående føling med begge for at klare sig. Det havde Lange, og her var en afgørende forskel fra vilkårene i Rudkøbing, hvor politikken hurtigt var til at overse. Der var ikke flere enerådende og indbyrdes stridende lokale fyrster at tækkes på Langeland. 
I 1992 er der kommet ikke mindre end to nye selvstændige bøger om Mads Lange. Den ene er af forfatteren Hans Gregersen, der har sat sig den opgavemed nye, flest nutidige, billeder, menellers hovedsageligt på grundlag af Aage Krarup Nielsens tekst at genfortælle historien om Mads Lange. Man kan tvivle på, at den vil nå de fem oplag som forlægget, men i en tid, hvor det eksotiske påny er i vælten, vil den have sit publikum ${ }^{9}$. Klogeligt er de barbrystede piger udeladt, da konkurencen på det gebet er en anden og mere ulige end i Aage Krarup Nielsens tid.

Den anden bog må fremkalde større interesse hos lange'anere (som man vist nu kan tillade sig at kalde de efterhånden mange, der sluger alt om købmand Lange) og andre med hang til det eksotiske. Forfatteren, fhv. overlæge Paul Andresen er i slægt med Mads Lange og har i den grad kastet sin kærlighed på forfaderen, at det er nået ud over den private genealogiske interesse, idet han ved mange og gentagne besøg har stiftet nære relationer til Langes efterkommere på Bali. Det er alt overvejende dem, Balis sultaner og deres familier, bogen handler om, mens Langes egen historie kun danner indledningen. Det er et klogt valg, for på det punkt er det stadig ikke rigtigt til at komme forbi Krarup Nielsens bog. Dertil er der dukket for lidt nyt materiale op. Omvendt er der masser af nyt om efterkommerne, hvis det har interesse, men så eventyrlig, som Mads Langes historie er deres ikke. Man får et godt indtryk af det officielle liv og sultan-skifter på Bali, som skildres med sympati af forfatteren. Her går tekst og billeder godt i spand sammen ${ }^{10}$. Set med vestlige briller er sympatien måske overdreven. Gæsten har ikke villet genere sine aner og værter på nogen måde, selv om nogle kritiske ord om den politiske, repræsentative kultur og mangel på reel medindflydelse måske kunne have været på sin plads.

Efter dette er kun tilbage at spørge: hvad bliver det næste om Mads Lange, som med forsinkelse i den grad er sluppet igennem historiens nåleøje? Det er en historie i sig selv.

\section{Noter}

1 Avisnotitser m.m. findes i Håndskriftafdelingen, Ny kgl. Samling 2831-2

2 Hele dette materiale findes i Håndskriftafdelingen, Ny kgl. Samling 2831-2. Ierindringerne Mitlivs eventyrrejse, 1964, genfortæller Krarup 
Nielsen med varme historien om Mads Lange (s. 152-157), idet han understreger, at han ikke har tildigtet noget i bogen fra 1925 .

3 Ud over testamentet og oplysningerne om opsætningen af en mindesten over Mads Langei 1927, ændrede Krarup Nielsen ikke senere i teksten, selv om nye kilder dukkede op. Engelsk kopi af testamentet i Håndskriftafdelingen, Ny kgl.Samling 2828-2.

4 I biblioteksteknisk forstand var 2. oplag en ny udgave, men vel af kommercielle grunde foretrak forlaget et reklamere med et højt oplagstal i stedet.

5 Inger Wulff: Mads Langes gaver fra Bali. Fra Nationalmuseets Arbejdsmark 1954, s. 83-94.
6 Leo Buschardt: Mads Langes balinesiske brevarkiv. Fund og Forskning II, 1955, s.125-138. P. Voorhoeve: Mads Langes's Malay and Balinese Letters. Catalogue of Indonesian Manuscripts. Part 2, Kbh. 1977, s. 148-155.

7 The Mads Lange Connection. Indonesia no. 32, 1981, s. 16-48.

8 På spor af Mads Lange. En dansk handelsmand i Østasien i det nittende århundrede. Erhvervshistorisk Årbog 1990, s. 7-43.

9 Mads Lange. Konge af Bali. 1992. $128 \mathrm{~s}$.

10 Mads Lange fra Bali og hans efterslægt Sultanerne af Johor. 1992 (Odense University Studiesin History and Social Sciences vol. 142). 184 s. 